\title{
Thermal Characterization of Malaysian Biomass via Thermogravimetric Analysis
}

\author{
Vekes Balasundram ${ }^{1}$, Noorhaza Alias ${ }^{1}$, Norazana Ibrahim*1, Rafiziana Md. Kasmani ${ }^{1}$, Ruzinah Isha ${ }^{2}$, Mohd. \\ Kamaruddin Abd. Hamid ${ }^{3}$, Hasrinah Hasbullah ${ }^{3}$ \\ ${ }^{1}$ Clean and Efficient Energy Research Group, Faculty of Chemical and Energy Engineering, Universiti \\ Teknologi Malaysia, 81310 Johor Bahru, Johor, Malaysia \\ ${ }^{2}$ Faculty of Chemical and Natural Resources Engineering, Universiti Malaysia Pahang, Lebuhraya Tun \\ Razak, 26300, Gambang, Kuantan, Pahang, Malaysia \\ ${ }^{3}$ Faculty of Chemical and Energy Engineering, Universiti Teknologi Malaysia, 81310 Johor Bahru, Johor, \\ Malaysia \\ *Corresponding author: norazana@utm.my
}

\section{Article History}

Received: March 01, 2018

Received in revised form: May 20, 2018

Accepted: June 06, 2018

Published: July 30, 2018

\begin{abstract}
In this work, thermal degradation behavior of six local biomasses such as empty fruit bunch, rice husk, coconut pulp, saw dust, coconut shell, and sugarcane bagasse in Malaysia via pyrolysis was studied. The pyrolysis process was carried out from 25 to $700{ }^{\circ} \mathrm{C}$ under nitrogen atmosphere flowing at $150 \mathrm{ml} / \mathrm{min}$ via a thermogravimetric analyzer. The effect of biomass type was investigated on pyrolysis behavior. The particle size of biomass was in the range of $0.3 \leq \mathrm{dp}_{1}<0.5$ $\mathrm{mm}$, whereas the heating rate was fixed at $80{ }^{\circ} \mathrm{C} / \mathrm{min}$. The thermogravimetric analysis (TGA) data were divided into three phases of degradation: moisture evolution, hemicellulose-cellulose degradation, and lignin degradation. The results showed that all biomass samples degraded between 25 and $170{ }^{\circ} \mathrm{C}$ in Phase I of moisture evolution. Among the biomass samples, coconut pulp achieved the highest mass loss (81.9\%) in Phase II of hemicellulose-cellulose degradation. Lignin in all biomass samples gradually degraded from 450 to $700{ }^{\circ} \mathrm{C}$ in Phase III of lignin degradation. This study provides an important basis in understanding the intrinsic thermochemistry behind degradation reactions.
\end{abstract}

Keywords: Biomass, pyrolysis, thermogravimetric analysis.

\subsection{INTRODUCTION}

Biomass is a well-known renewable resource with great potential as an alternative energy to fossil fuels [1]. Biomass fractions in Malaysia can be divided into four categories according to their sources such as oil palm, rice, sugarcane bagasse, and municipal waste [2]. In addition, with a total quantity of 72,962 kton/yr and 5,863 Gwh potential annual generation, biomass serves as a viable alternative energy source [3]. Therefore, to convert biomass into renewable fuel, various conversion technologies such as pyrolysis, gasification, and torrefaction have been used. However, pyrolysis of biomass has gained attention that could maximize yield of organic liquids [4]. During flash pyrolysis, biomass is thermally decomposed without an organizing agent to produce solid charcoal, liquid oil, and gases. Biomass is made up of lignocellulosic structure that consists of cellulose, hemicellulose, and lignin, which have different thermal behaviors that influence the quantities and compositions of pyrolysis products [5]. Due to the carbohydrate structure, this oil is highly oxygenated as compared to conventional fuels. In order to obtain the highest possible liquid yield, high heating rates of biomass particle and short residence time at the temperature of 450 to $600{ }^{\circ} \mathrm{C}$ are required [6].

Although biofuel has low energy density of approximately $15-20 \mathrm{MJ} / \mathrm{kg}$, it produces less carbon monoxide and soot during combustion [7]. The yield of pyrolysis products depends on reaction temperature, type of biomass, heating rates, 
particle size of biomass, and type of reactors [8]. Thermogravimetric analysis (TGA) is one of the major thermal analysis techniques used to study the thermal behavior of carbonaceous materials [9]. In addition, TGA provides a semiquantitative understanding of thermal degradation processes occurring during pyrolysis of biomass [10]. On the other hand, a derivative thermogravimetric (DTG) curve is needed to measure the apparent mass loss of biomass samples [11]. TGA is generally preferred due to its simplicity in expressing the thermal behavior of biomass [12]. The effect of heating rate and final pyrolysis temperature on material decomposition using TGA was studied by a number of researchers. Yiin et al. [13] in their work showed a distinct systematic shift of the region of maximum rate of weight loss to higher temperatures when the heating rate was increased during biomass pyrolysis via TGA. In addition, the influence of pyrolysis temperature showed higher weight losses when pyrolyzed at a higher temperature $\left(>500{ }^{\circ} \mathrm{C}\right)$ [14]. In TG-DTG analysis, more than one peak commonly appears, which can be assigned to cellulose, hemicellulose, and lignin [15, 16].

Omar et al. [17] claimed that the degradation temperatures of hemicellulose and cellulose are in the range of 220-300 and $300-340{ }^{\circ} \mathrm{C}$, respectively. In addition, thermal degradation of lignin starts at lower temperature than cellulose, but it decomposes at a lower rate than cellulose and hemicellulose, which leaves a higher percentage of residue. Very few attempts have been carried out to study the thermal degradation of coconut pulp and saw dust using TGA in Malaysia. Moreover, there are a limited number of research that have dedicated their investigation to these biomasses. Mansaray and Ghaly [7] used TGA for rice husks in pure nitrogen atmosphere at heating rates of $10-50{ }^{\circ} \mathrm{C} / \mathrm{min}$. Raveendran et al. [18] studied 13 different biomass samples, in which sugarcane bagasse, coconut shell, and rice husk were included. In the present study, TGA was used to investigate the thermal degradation behavior of six local Malaysian biomasses: empty fruit bunch (EFB), rice husk, coconut pulp, sugarcane bagasse, saw dust, and coconut shell. In addition, this study was also conducted to determine the degradation temperature range of biomass components, the initial degradation temperature, and the mass loss $(\%)$ at each phase of degradation. These analyses will provide important information for potential biofuel production from these local biomasses.

\subsection{METHODOLOGY}

\subsection{Biomass Feedstock Preparation}

All six types of local biomasses used in this study (EFB, rice husk, coconut pulp, sugarcane bagasse, saw dust, and coconut shell) were easily available in Malaysia. EFB samples were obtained from the nearest palm oil plantation, rice husk samples were supplied by Padiberas Nasional Berhad (BERNAS), whereas sugarcane bagasse, coconut pulp, and coconut shell were collected from local producers. All samples were crushed into smaller size and then dried in an oven at $105 \pm 2{ }^{\circ} \mathrm{C}$ to remove any moisture content. Then, the biomass samples were sieved to obtain particle size of $0.30 \leq$ $\mathrm{dp} 1<0.50 \mathrm{~mm}$. Lastly, the samples were kept in a separate closed container to minimize moisture absorption from the surrounding humidity.

\subsection{Biomass Characterization}

Biomass characterization was performed in order to obtain the physicochemical properties such as ultimate, proximate, and high heating value (HHV) of each biomass feedstock. Ultimate analysis was carried out by using an elemental analyzer to determine the compositions of carbon, hydrogen, nitrogen, sulfur, and oxygen in biomass feedstock. Proximate analysis was conducted by using a thermogravimetric analyzer to analyze the amount of volatile matter (VM), fixed carbon (FC), moisture content, and ash content in the samples. Meanwhile, the fixed carbon was obtained by subtracting from 100 the sum of volatile, ash, and moisture content. Lastly, the ultimate analysis of biomass samples was performed via an elemental analyzer (Euro EA 3000 using Callidus Software interface Version 4.1) to measure carbon, hydrogen, nitrogen, and sulfur contents. Then, oxygen content was calculated by difference. The HHV of biomass samples was measured using a bomb calorimeter.

\subsection{TGA Pyrolysis}

TGA pyrolysis of biomass samples was carried out under nitrogen $\left(\mathrm{N}_{2}\right)$ atmosphere flowing at $150 \mathrm{ml} / \mathrm{min}$. Biomass samples between 0.5 and $1.0 \mathrm{mg}$ were pyrolyzed to a maximum temperature of $700{ }^{\circ} \mathrm{C}$. The samples were first heated to $110^{\circ} \mathrm{C}$ and maintained for $30 \mathrm{~min}$ to remove any moisture. After that, the samples were individually heated at the rate of $80{ }^{\circ} \mathrm{C} / \mathrm{min}$ until it reached the maximum temperature at the particle size of $0.30 \leq \mathrm{dp} 1<0.50 \mathrm{~mm}$. The experiment was repeated for each type of biomass. Graphs of mass loss over temperature and rate of mass loss over temperature were plotted to observe the degradation behavior for each type of biomass. 


\subsection{RESULTS AND DISCUSSION}

\subsection{Physicochemical Properties of Biomass Feedstock}

Proximate and ultimate analyses were conducted to study the properties of each biomass feedstock as shown in Table 1 . The moisture content of saw dust was considerably higher at $9.55 \mathrm{wt} \%$ compared to other biomass samples. This might be due to the lower surface area to volume ratio, resulting in lower evaporation rate; thus, saw dust has higher ability to store water [17]. In addition, this could also be due to the lignocellulosic material that made up saw dust, giving it strong cell walls with high ability to hold water in the cells. Notably, saw dust comprised of $31.50 \mathrm{wt} \%$ cellulose and $21.40 \mathrm{wt} \%$ hemicellulose as shown in Table 2. Furthermore, saw dust had a lower HHV of $17.03 \mathrm{MJ} / \mathrm{kg}$ than other biomass samples. This is due to the high moisture content in saw dust that would negatively influence the thermal treatment by decreasing its calorific value, which directly reflects the devolatilization rate of pyrolysis, resulting in longer reaction time [19, 20]. In addition, this could cause ignition and combustion problems [21]; therefore, it could incur additional costs for drying. However, moisture might be beneficial for microwave heating as water is highly absorbent of microwave and might favor gasification reaction, producing high syngas products [22]. From a previous study, it was found that at lower pyrolysis temperature, higher initial moisture contents resulted in maximum liquid yield and high HHV of liquid product with low viscosity compared to dry feed [23]. Conversely, coconut pulp has high HHV than other biomasses.

Table 1. Physicochemical properties of biomass feedstock

\begin{tabular}{|c|c|c|c|c|c|c|}
\hline \multirow{2}{*}{ Physicochemical Properties } & \multicolumn{3}{|c|}{ Biomass } & \multirow[b]{2}{*}{$\begin{array}{l}\text { Saw } \\
\text { Dust }\end{array}$} & \multirow[b]{2}{*}{$\begin{array}{c}\text { Coconut } \\
\text { Shell }\end{array}$} & \multirow[b]{2}{*}{$\begin{array}{c}\text { Sugarcane } \\
\text { Bagasse }\end{array}$} \\
\hline & EFB & $\begin{array}{c}\text { Rice } \\
\text { Husk }\end{array}$ & $\begin{array}{c}\text { Coconut } \\
\text { Pulp } \\
\end{array}$ & & & \\
\hline \multicolumn{7}{|l|}{ Proximate Analysis (d.b. wt\%) } \\
\hline $\begin{array}{l}\text { Moisture Content } \\
\text { Ash Content } \\
\text { Volatile Matter } \\
\text { Fixed Carbon }{ }^{\mathrm{a}}\end{array}$ & $\begin{array}{c}2.40 \\
4.02 \\
78.49 \\
15.09\end{array}$ & $\begin{array}{c}6.73 \\
17.06 \\
55.88 \\
20.33\end{array}$ & $\begin{array}{c}6.10 \\
0.57 \\
75.74 \\
18.59\end{array}$ & $\begin{array}{c}9.55 \\
0.45 \\
58.28 \\
31.72\end{array}$ & $\begin{array}{c}0.50 \\
2.90 \\
71.10 \\
25.50\end{array}$ & $\begin{array}{c}4.99 \\
2.34 \\
73.50 \\
19.17\end{array}$ \\
\hline \multicolumn{7}{|l|}{ Ultimate Analysis (d.b. wt\%) } \\
\hline 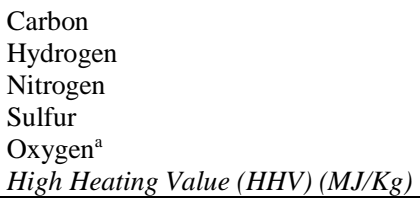 & $\begin{array}{c}44.71 \\
6.76 \\
0.21 \\
0.41 \\
43.89 \\
21.77 \\
\end{array}$ & $\begin{array}{c}38.22 \\
5.88 \\
0.68 \\
0.07 \\
38.09 \\
17.91 \\
\end{array}$ & $\begin{array}{c}55.84 \\
10.17 \\
1.18 \\
0.12 \\
32.12 \\
30.22 \\
\end{array}$ & $\begin{array}{c}39.44 \\
6.14 \\
0.50 \\
0.04 \\
53.43 \\
17.03 \\
\end{array}$ & $\begin{array}{c}47.49 \\
7.22 \\
0.50 \\
0.04 \\
41.85 \\
19.79 \\
\end{array}$ & $\begin{array}{c}41.98 \\
6.04 \\
0.53 \\
0.24 \\
48.87 \\
18.60 \\
\end{array}$ \\
\hline
\end{tabular}

${ }^{\mathrm{a} C}$ Calculated by difference

Table 2. Biomass lignocellulose compositions

\begin{tabular}{lccc}
\hline \multicolumn{1}{c}{ Biomass } & \multicolumn{3}{c}{ Compositions (wt \%) } \\
\cline { 2 - 4 } & Hemicellulose & Cellulose & Lignin \\
\hline Sugarcane Bagasse & & & \\
EFB $^{[17]}$ & 23.30 & 40.90 & 19.00 \\
Coconut Shell $^{[34]}$ & 21.60 & 23.70 & 29.20 \\
Coconut Pulp $_{\text {Rice Husk }}^{[29]}$ & 21.03 & 41.84 & 39.17 \\
Saw Dust $^{[29]}$ & - & - & - \\
& 27.30 & 34.10 & 17.90 \\
& 21.40 & 31.50 & 28.90 \\
\hline
\end{tabular}

As shown in Table 1, it was observed that EFB had the highest volatile matter at 78.49 wt $\%$, followed by coconut pulp at $75.74 \mathrm{wt} \%$. Hence, the high volatile matter in EFB suggests that it is highly preferred as liquid fuel [24]. Other biomasses that produced lower volatile content than EFB are as follows: sugarcane bagasse $(73.50 \mathrm{wt} \%)$, coconut shell $(71.10 \mathrm{wt} \%)$, saw dust (58.28 wt\%), and rice husk (55.88 wt\%). Moreover, it was observed that rice husk contained the highest ash content at $17.06 \mathrm{wt} \%$ compared to other agricultural residues, which is consistent with literature [25, 26], and this will result in low bio-oil quality. Consequently, the high content of ash would negatively affect HHV [21]. The energy content of biomass sample is largely dependent on its chemical composition (carbon, hydrogen, and oxygen) and it is negatively affected by the inclusion of inorganic elements and moisture [27]. The elemental compositions of carbon (C), hydrogen $(\mathrm{H})$, and oxygen $(\mathrm{O})$ are the main components found in the ultimate analyses. In addition, $\mathrm{C}$ and $\mathrm{H}$ are oxidized during combustion by exothermic reaction and formed $\mathrm{CO}_{2}$ and $\mathrm{H}_{2} \mathrm{O}$, respectively [28]. The content of $\mathrm{C}$ and $\mathrm{H}$ contributes positively to calorific value, whereas the content of $\mathrm{O}$ reduces calorific value. The ultimate analysis showed that the carbon content in coconut pulp was the highest (55.84 wt\%), whereas rice husk had the lowest amount (38.22 wt\%), 
which explained the higher calorific value in coconut pulp. The presence of other elements such as hydrogen, nitrogen, and sulfur was almost similar for all biomasses except for coconut pulp that had higher hydrogen content (10.17 wt\%).

\subsection{TGA Pyrolysis}

\subsubsection{Effect of Biomass Type}

The results of TGA analyses are shown in Figure 1(a) and (b), which show the weight loss curves (TG) and derivative thermogravimetric (DTG) evolution profiles respectively, as a function of temperature, for all biomasses heated at a fixed heating rate $\left(80^{\circ} \mathrm{C} / \mathrm{min}\right)$ and at a particle size of $0.3 \leq \mathrm{dp} 1<0.5 \mathrm{~mm}$. In general, the pyrolysis of biomass can be divided into three phases: drying and evaporation of light components (Phase I), devolatilization of hemicellulose and cellulose (Phase II), and decomposition of lignin (Phase III) [29, 30]. Phase I occurred at the temperature below $150{ }^{\circ} \mathrm{C}$, Phase II started to devolatize from 150 to $450{ }^{\circ} \mathrm{C}$, and finally Phase III was attained at the temperature above $450{ }^{\circ} \mathrm{C}$, which can be observed in Figure 1(a) and (b). The TGA-DTG curves of the samples showed the first stage of weight loss from 25 to $150{ }^{\circ} \mathrm{C}$. The derivative plot had a separate peak for this zone of weight loss. This might be due to the evolution of water and light volatile compounds during the degradation of biomass via pyrolysis in TGA.

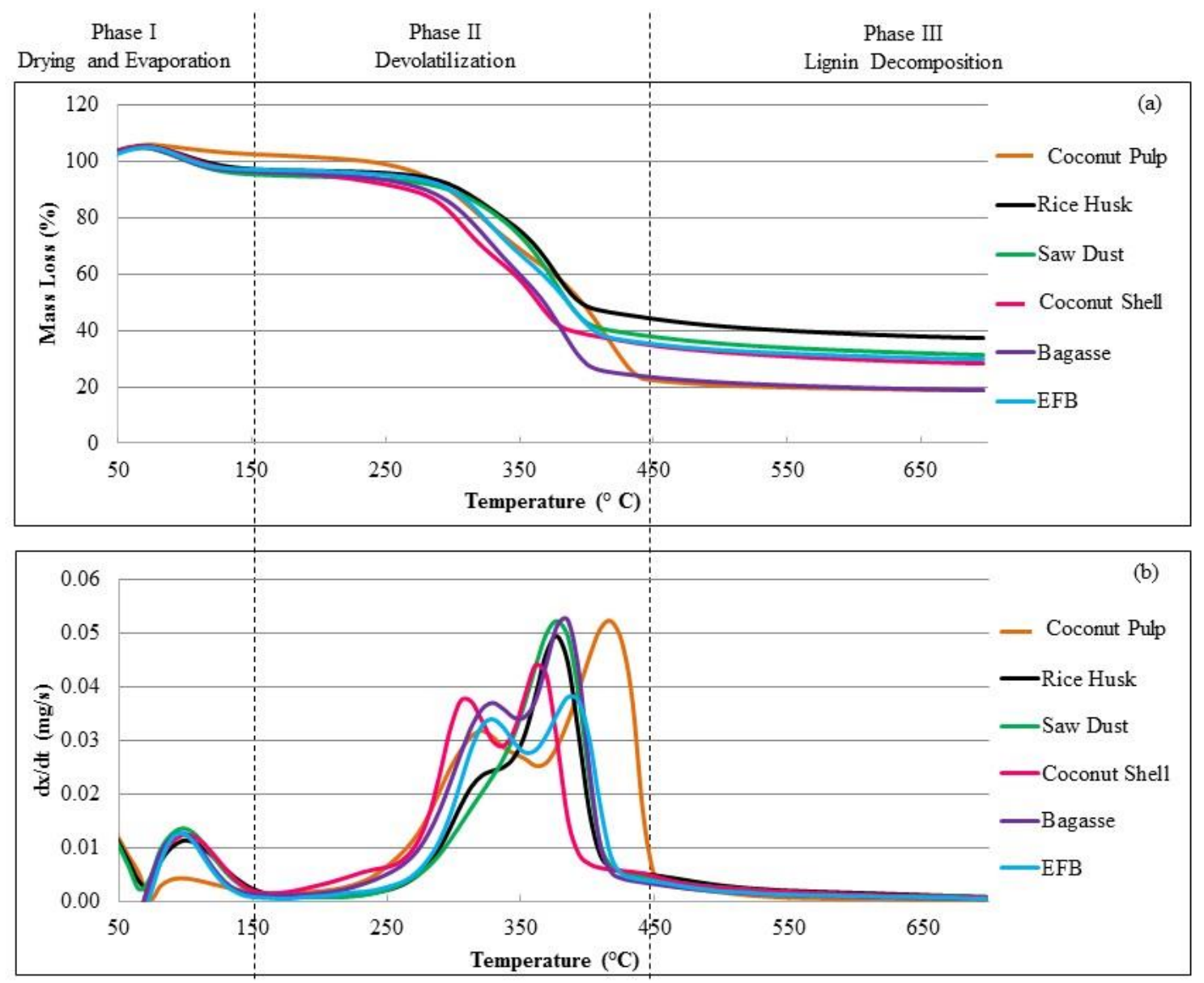

Figure 1. Plots of (a) thermogravimetric analysis and (b) derivative thermogravimetric for $0.3 \leq \mathrm{dp}_{1}<0.5 \mathrm{~mm}$ at 80 ${ }^{\circ} \mathrm{C} / \mathrm{min}$

As shown in Figure 1 (b), it was observed that Phase I (moisture evolution) in all biomass samples occurred between 25 and $170^{\circ} \mathrm{C}$. Thus, it can be concluded that all biomass samples have a similar pattern of moisture evolution in Phase I. In detail, Phase I was identified between 25 and $121^{\circ} \mathrm{C}$ for coconut shell as indicated in Table 3 and has high mass loss (5.3\%) among other biomass samples in Phase I. In addition, it directly reflects low moisture content at $0.50 \mathrm{wt} \%$ as indicated in Table 1. The first peak in the DTG curve corresponds to the moisture released from the biomass feedstock (refer to Figure 1(b)). The temperature at which the overall degradation starts is termed as the initial degradation temperature $\left(\mathrm{T}_{\text {ini }}\right)$. It is the initial point where the curve starts to drop in the TG curve as shown in Figure 1(a). The $\mathrm{T}_{\text {ini }}$ of 
hemicellulose-cellulose was developed between 177 and $249^{\circ} \mathrm{C}$ for all biomass samples. Meanwhile, sugarcane bagasse had a lower $\mathrm{T}_{\text {ini }}$ at $177{ }^{\circ} \mathrm{C}$ compared to other biomass samples (refer to Table 3 ). This might be due to the low moisture content evolved in Phase I (moisture evolution), which was 3.6\%. It leads to fast evaporation and proceeds to Phase II at low $\mathrm{T}_{\text {ini. }}$. In contrary, saw dust started to degrade at high temperature $\left(249{ }^{\circ} \mathrm{C}\right)$ in a single peak. Ghaly and Mansaray (1999) reported that different biomass has different degradation temperature due to the variance in chemical compositions present in biomass [31].

As shown in Figure 1(a), it was noticed that coconut pulp achieved the highest mass loss of 81.0\%, which might be due to high volatile matter. On the other hand, the order of mass loss percentage in Phase II can be ranked as follows: sugarcane bagasse $(71.7 \%)$, EFB $(60.2 \%)$, coconut shell $(57.8 \%)$, saw dust $(56.2 \%)$, and rice husk $(51.6 \%)$. In general, lignocellulose is made up of three major constituents: cellulose, hemicellulose, and lignin. Cellulose is composed of $\beta$ 1,4 glucan chains associated with one another through extensive hydrogen bonding, whereas hemicellulose is characterized by linear polymers and they are usually substituted with other sugar side chains to prevent the formation of crystalline structures [31]. In regards to lignin, it is a phenolic polymer that essentially encases the polysaccharides of cell walls, producing a strong and durable composite material resistant to enzymatic attack [32]. In addition, from previous studies done by researchers, it has been recognized that the lignocellulosic structure of biomass can be qualitatively identified by means of DTG curve [33,34]. Biomass is composed of different components including moisture, extractives, cellulose, hemicellulose, lignin, and ash. These components degrade at different temperatures and thermal behavior [30]. Hemicellulose degrades at a temperature lower than $350{ }^{\circ} \mathrm{C}$, cellulose degrades between 250 and $500{ }^{\circ} \mathrm{C}$, and lignin degrades at a temperature above $400{ }^{\circ} \mathrm{C}$ [35]. Table 2 shows the results of chemical compositions of the biomass samples determined by wet chemical method from the study done previously. It can be seen that sugarcane bagasse and coconut shell have much higher cellulose content at 40.90 and $41.80 \mathrm{wt} \%$, respectively.

Table 3. Thermal degradation of biomass samples

\begin{tabular}{|c|c|c|c|c|c|}
\hline Biomass & Phase & $\begin{array}{c}\text { Temperature } \\
\text { Range }\left({ }^{\circ} \mathbf{C}\right)\end{array}$ & $\begin{array}{c}\text { Mass } \\
\text { Loss }(\%)\end{array}$ & $\begin{array}{c}\text { Initial } \\
\text { Degradation } \\
\text { Temperature, } \\
\mathbf{T}_{\text {ini }}\left({ }^{\circ} \mathbf{C}\right) \\
\end{array}$ & $\begin{array}{c}\text { Residual } \\
\text { Weight }(\%) \\
\text { at } 700{ }^{\circ} \mathrm{C}\end{array}$ \\
\hline Sugarcane & I & $25-113$ & 3.6 & 177 & 18.9 \\
\hline \multirow[t]{2}{*}{ Bagasse } & II & $177-432$ & 71.7 & & \\
\hline & III & $432-696$ & 5.6 & & \\
\hline \multirow[t]{3}{*}{ EFB } & I & $25-113$ & 4.5 & 193 & 28.9 \\
\hline & II & $193-433$ & 60.2 & & \\
\hline & III & $433-696$ & 6.4 & & \\
\hline \multirow[t]{3}{*}{ Coconut Shell } & I & $25-113$ & 5.3 & 201 & 28.2 \\
\hline & II & $201-416$ & 57.8 & & \\
\hline & III & $416-696$ & 8.9 & & \\
\hline \multirow[t]{3}{*}{ Coconut Pulp } & I & $25-169$ & 3.9 & 233 & 12.6 \\
\hline & II & $233-448$ & 81.9 & & \\
\hline & III & $448-696$ & 1.4 & & \\
\hline \multirow[t]{3}{*}{ Rice Husk } & I & $25-121$ & 5.2 & 241 & 37.5 \\
\hline & II & $241-448$ & 51.6 & & \\
\hline & III & $448-696$ & 6.9 & & \\
\hline \multirow[t]{3}{*}{ Saw Dust } & I & $25-105$ & 5.0 & 249 & 34.2 \\
\hline & II & $249-448$ & 56.2 & & \\
\hline & III & $448-696$ & 4.5 & & \\
\hline
\end{tabular}

Table 4. Thermal degradation rate of biomass samples

\begin{tabular}{lcccc}
\hline Biomass & $\begin{array}{c}\text { First Peak } \\
\text { Temperature, } \\
\mathbf{T}_{\text {1peak }}\left({ }^{\circ} \mathbf{C}\right)\end{array}$ & $\begin{array}{c}\text { Degradation } \\
\text { Rate at } \\
\mathbf{T}_{\text {1peak }}, \mathbf{d x} / \mathbf{d t} \\
(\mathbf{m g} / \mathbf{s})\end{array}$ & $\begin{array}{c}\text { Second Peak } \\
\text { Temperature, } \\
\mathbf{T}_{\text {2peak }}\left({ }^{\circ} \mathbf{C}\right)\end{array}$ & $\begin{array}{c}\text { Degradation } \\
\text { Rate at } \\
\mathbf{T}_{\text {2peak }}, \mathbf{d x} / \mathbf{d t} \\
(\mathbf{m g} / \mathbf{s})\end{array}$ \\
\hline Sugarcane Bagasse & 328 & 0.0369 & 384 & 0.0523 \\
EFB & 328 & 0.0339 & 384 & 0.0380 \\
Coconut Shell & 305 & 0.0375 & 360 & 0.0442 \\
Coconut Pulp & 320 & 0.0318 & 416 & 0.0522 \\
Rice Husk & 320 & 0.0234 & 376 & 0.0495 \\
Saw Dust & 376 & 0.0522 & - & - \\
\hline
\end{tabular}

In addition, coconut shell had higher lignin content of $39.1 \mathrm{wt} \%$ than other biomass samples (refer to Table 2). Meanwhile, rice husk had the highest hemicellulose content (27.30 wt \%). As shown in Figure 1(b), it was observed that there were two peaks in Phase II for coconut pulp, coconut shell, sugarcane bagasse, rice husk, and EFB, in which the first and second peaks represent the thermal decomposition of hemicellulose and cellulose, respectively. In addition, sugarcane 
bagasse and EFB exhibited peaks of hemicellulose and cellulose at the temperature of 328 and $384{ }^{\circ} \mathrm{C}$, respectively. Contrarily, the thermal degradation rate for sugarcane bagasse was high at both hemicellulose and cellulose peaks than EFB. This might be due to high cellulose content in sugarcane bagasse at $40.9 \mathrm{wt} \%$ than EFB (23.7 wt \%) (Table 2). Thus, it reflects the degradation rate of sugarcane bagasse at cellulose peak is high $(0.0523 \mathrm{mg} / \mathrm{s})$, which indicates higher reactivity than EFB with the degradation rate of $0.0380 \mathrm{mg} / \mathrm{s}$. Coconut pulp and rice husk exhibited similar hemicellulose peak temperature at $320^{\circ} \mathrm{C}$. However, coconut pulp had higher degradation rate $(0.0318 \mathrm{mg} / \mathrm{s})$, whereas rice husk had degradation rate of $0.0234 \mathrm{mg} / \mathrm{s}$. In contrast, the cellulose peak temperature for coconut pulp and rice husk was achieved at $416{ }^{\circ} \mathrm{C}(0.0522 \mathrm{mg} / \mathrm{s})$ and $376{ }^{\circ} \mathrm{C}(0.0495 \mathrm{mg} / \mathrm{s})$, respectively.

For coconut shell, the peaks of hemicellulose and cellulose occurred at 305 and $360{ }^{\circ} \mathrm{C}$, respectively. The hemicellulose content in coconut shell was $21.0 \mathrm{wt} \%$, which was reflected by low degradation rate of $0.0375 \mathrm{mg} / \mathrm{s}$. Meanwhile, coconut shell degraded at high degradation rate of $0.0442 \mathrm{mg} / \mathrm{s}$ due to high cellulose composition (41.8 wt \%) than other biomass samples. When saw dust was tested, only a single peak (hemicellulose-cellulose) was exhibited. The peak was developed at high temperature $\left(376{ }^{\circ} \mathrm{C}\right)$ and high degradation rate $(0.0522 \mathrm{mg} / \mathrm{s})$. This could be due to the hemicellulose $(21.4 \mathrm{wt} \%)$ and cellulose $(31.5 \mathrm{wt} \%)$ contents that degrade simultaneously in a single peak. A similar observation was reported elsewhere on the DTG curve of saw dust [29]. The study of lignocellulosic compounds is relevant to pyrolysis because the decomposition of these components occurs at different temperatures. It was noticed that the degradation rates of biomass were no longer significant as most volatiles had already been pyrolysed and the rest were converted into char and gases at above $650{ }^{\circ} \mathrm{C}$.

Industrial and commercial processes for gasification, pyrolysis, and liquefaction are usually designed for higher temperatures above $600{ }^{\circ} \mathrm{C}$ at a large scale [14]. In this study, the residual weight of sample was compared at the temperature closer to $700{ }^{\circ} \mathrm{C}$. It was observed that the residual weight of rice husk (37.5\%) was higher than that of saw dust (34.2\%), EFB (30.0\%), coconut shell (28.2\%), sugarcane bagasse (18.9\%), and coconut pulp (12.6\%). The residual weight may be attributed to the presence of inorganic mineral content in biomass [30]. TGA measurements were also used to generate data equivalent to proximate analysis, namely moisture, volatile matter, fixed carbon, and ash contents as shown in Figure 1(a) and (b). The results are presented in Table 1. All biomass samples were ashed in air at $700{ }^{\circ} \mathrm{C}$. The residual weight percentage of coconut shell was high (37.5\%) compared to other samples. This is due to high ash content in coconut shell (17.06 wt \%). However, rice husk contained high ash content among other samples, which resulted in high residual weight as shown in Table 4.

\subsection{CONCLUSION}

Thermogravimetric analysis on six different biomass samples (EFB, rice husk, coconut pulp, saw dust, coconut shell, and sugarcane bagasse) was conducted at a heating rate of $80^{\circ} \mathrm{C} / \mathrm{min}$ in an inert nitrogen atmosphere. The thermal degradation temperature range of biomass components, the initial degradation temperature, and the mass loss of biomass samples at each phase of degradation were determined. From proximate analysis, coconut pulp contained high volatile matter that gave high volatility and reactivity advantages, which are suitable for liquid fuel production. Ultimate analysis showed that coconut pulp has high carbon content, which explains the higher calorific value in coconut pulp. During thermal degradation, sugarcane bagasse showed high thermal degradation rate of $0.0523 \mathrm{mg} / \mathrm{s}$, which corresponded to high cellulose content. The higher the cellulosic content of sugarcane bagasse, the higher its thermal degradation rate. A similar single peak was observed for coconut shell at $368^{\circ} \mathrm{C}$. Thus, the three distinct reaction zones in the TG-DTG curve can provide an important basis in determining suitable properties of Malaysian biomasses and pyrolysis parameters for biofuel production via pyrolysis.

\section{Acknowledgements}

The authors would like to acknowledge the financial support by Universiti Teknologi Malaysia, the Ministry of Higher Education (MOHE) Malaysia (Q.J130000.2546.20H18 and Q.J130000.2546.14H48), and Universiti Malaysia Pahang (RDU1703242).

\section{References}

[1] Garcia-Bacaicoa, P., J. F. Mastral, J. Ceamanos, C. Berrueco, S. Serrano. 2008. Gasification of biomass/high density polyethylene mixtures in a downdraft gasifier. Bioresour Technology. 99: 5485-5491.

[2] Balasundram, V., N. Ibrahim, R.M. Kasmani, R. Isha, M.KA. Hamid, H. Hasrinah, R.R. Ali. 2018. Catalytic upgrading of Sugarcane bagasse pyrolysis vapours over rare earth metal (Ce) loaded HZSM-5: Effect of catalyst to biomass ratio on the organic compounds in pyrolysis oil. Applied Energy. 220: 787-799.

[3] Zafar. S. 2015. Bioenergy Developments in Malaysia. Available: http://www.bioenergyconsult.com/tag/biomass-resources-in-malaysia/ 
[4] Balasundram, V., N. Ibrahim, R.Md. Kasmani, M.K.A. Hamid, R. Isha, H. Hasrinah, R.R. Ali. 2017. Thermogravimetric catalytic pyrolysis and kinetic studies of coconut copra and rice husk for possible maximum production of pyrolysis oil. Journal of Cleaner Production. 167: $218-228$.

[5] Pütün, A. E. 2010. Biomass to Bio-Oil via Fast Pyrolysis of Cotton Straw and Stalk. Energy Sources. 24: $275-285$.

[6] Acikgoz. C., and O. M. Kockar. 2007. Flash pyrolysis of linseed (Linum usitatissimum L.) for production of liquid fuels. Journal of Analytical and Applied Pyrolysis. 78: 406-412.

[7] Mansaray. K.G., and A. E. Ghaly. 1998. THERMAL DEGRADATION OF RICE HUSKS IN NITROGEN ATMOSPHERE. Bioresource Technology. 65: 13-20.

[8] Mendes, F.L., V.L. Ximenes, M.B.B. de Almeida, D.A. Azevedo, N.S. Tessarolo, A.R. Pinho. 2016. Catalytic pyrolysis of sugarcane bagasse and pinewood in a pilot scale unit. Journal of Analytical and Applied Pyrolysis. 122: 395-404.

[9] Balasundram, V., N. Ibrahim, M.D.M. Samsudin, R.Md. Kasmani, M.K.A. Hamid, R. Isha, H. Hasrinah. 2017. Thermogravimetric Studies on the Catalytic Pyrolysis of Rice Husk. Chemical Engineering Transactions. 56: 427-432.

[10] Vyazovkin, S., A.K. Burnham, J.M. Criado, L.A. Pérez-Maqueda, C. Popescu, N., Sbirrazzuoli. 2011. ICTAC Kinetics Committee recommendations for performing kinetic computations on thermal analysis data. Thermochimica Acta. 520: 1-19.

[11] Balasundram, V., N. Ibrahim, R.Md. Kasmani, M.K.A. Hamid, R. Isha, H. Hasrinah, R.R. Ali. 2017. The Effect of Catalyst Loading (Ni$\mathrm{Ce} / \mathrm{Al}_{2} \mathrm{O}_{3}$ ) on Coconut Copra Pyrolysis via Thermogravimetric Analyser. Chemical Engineering Transactions. 56: $901-906$.

[12] Sheeba, K. N., J.S.C. Babu, and S. Jaisankar. 2010. The Reaction Kinetics for Coir Pith Pyrolysis in Thermogravimetric Analyzer. Energy Sources Part a-Recovery Utilization and Environmental Effects. 32: 1837-1850.

[13] Yiin, C.L., S., Yusup, A.T., Quitain, Y., Uemura, M., Sasaki, T., Kida. 2018. Thermogravimetric analysis and kinetic modeling of low-transitiontemperature mixtures pretreated oil palm empty fruit bunch for possible maximum yield of pyrolysis oil. Bioresource Technology. 255 : $189-197$.

[14] Parthasarathy, P., K.S. Narayanan, L. Arockiam. 2013. Study on kinetic parameters of different biomass samples using thermo-gravimetric analysis. Biomass and Bioenergy. 58: 58-66.

[15] Munir, S., S.S. Daood, W. Nimmo, A.M. Cunliffe, B.M. Gibbs. 2009. Thermal analysis and devolatilization kinetics of cotton stalk, sugar cane bagasse and shea meal under nitrogen and air atmospheres. Bioresource Technology. 100: 1413-1418.

[16] Vamvuka, D., E. Kakaras, E. Kastanaki, P. Grammelis. 2003. Pyrolysis characteristics and kinetics of biomass residuals mixtures with lignite. Fuel. 82: 1949-1960.

[17] Omar, R., A. Idris, R. Yunus, K. Khalid, M.I.A. Isma. 2011. Characterization of empty fruit bunch for microwave-assisted pyrolysis. Fuel. 90: 1536-1544.

[18] Raveendran, K., A. Ganesh, and K.C. Khilart. 1995. Influence if mineral matter on biomass pyrolysis characteristics. Fuel. 74 : $1812-1822$.

[19] Kataki, R., and D. Konwer. 2002. Fuelwood characteristics of indigenous tree species of north-east India. Biomass \& Bioenergy. 22 : $433-437$.

[20] de Diego, L.F., F. Garcia-Labiano, A. Abad, P. Gayán, J. Adánez. 2003. Effect of Moisture Content on Devolatilization Times of Pine Wood Particels in a Fludized Bed. Energy \& Fuels. 17: 285-290.

[21] Demirbas, A. 2005. Relationship between initial moisture content and the liquid yield from pyrolysis of sawdust. Energy Sources. 27: 823-830.

[22] Zabaniotou, A., O. Ioannidou, E. Antonakou, A. Lappas. Experimental study of pyrolysis for potential energy, hydrogen and carbon material production from lignocellulosic biomass. International Journal of Hydrogen Energy. 33: 2433-2444.

[23] Demirbas, A. 2008. Partial hydrogenation effect of moisture contents on the combustion oils from biomass pyrolysis. Energy Sources Part aRecovery Utilization and Environmental Effects. 30: 508-515, 2008.

[24] Demirbas, A. Combustion characteristics of different biomass fuels. Progress in Energy and Combustion Science. 30: 219-230, 2004.

[25] Colomba D.B., G. Signorelli, C.D. Russo, G. Rea. 1999. Product Distribution from Pyrolysis of Wood and Agricultural Residues. Ind. Eng Chem. Res. 38: 2216-2224.

[26] Mansaray, K.G., and A.E.Ghaly. 1999. Determination of kinetic parameters of rice husks in oxygen using thermogravimetric analysis. Biomass \& Bioenergy. 17: 19-31, 1999.

[27] El-Sayed, S.A., and M. E. Mostafa. 2015. Kinetic Parameters Determination of Biomass Pyrolysis Fuels Using TGA and DTA Techniques. Waste and Biomass Valorization. 6: 401-415.

[28] Sensoz, S. 2003. Slow pyrolysis of wood barks from Pinus brutia Ten. and product compositions. Bioresource Technology. 89: 307-311. 
[29] Goenka, R., P. Parthasarathy, N. K. Gupta, N. K. Biyahut, and S. Narayanan. 2015. Kinetic Analysis of Biomass and Comparison of its Chemical Compositions by Thermogravimetry, Wet and Experimental Furnace Methods. Waste and Biomass Valorization. 6: $989-1002$.

[30] Parthasarathy, P., K. S. Narayanan, and L. Arockiam. 2013. Study on kinetic parameters of different biomass samples using thermo-gravimetric analysis. Biomass \& Bioenergy. 58: 58-66.

[31] Ghaly, A.E., and K. G. Mansaray. 1999. Comparative study on the thermal degradation of rice husks in various atmospheres. Energy Sources. 21: $867-881$.

[32] Gomez, L.D., C.G. Steele-King, and S. J. McQueen-Mason. 2008. Sustainable liquid biofuels from biomass: the writing's on the walls. New Phytol. 178: 473-85.

[33] Chen, W.H., Y. J. Tu, and H. K. Sheen. 2010. Impact of dilute acid pretreatment on the structure of bagasse for bioethanol production. International Journal of Energy Research. 34: 265-274.

[34] Chen, W.H., and J. S. Wu. 2009. An evaluation on rice husks and pulverized coal blends using a drop tube furnace and a thermogravimetric analyzer for application to a blast furnace. Energy. 34: 1458-1466.

[35] White, J.E., W.J., Catallo, B.L., Legendre. 2011. Biomass pyrolysis kinetics: A comparative critical review with relevant agricultural residue case studies. Journal of Analytical and Applied Pyrolysis. 91: 1-33.

[36] Kastanaki, E., D. Vamvuka, P. Grammelis, E. Kakaras. 2002. Thermogravimetric studies of the behavior of lignite-biomass blends during devolatilization. Fuel Processing Technology. 77-78: 159-166. 